\title{
Analysis of Problems of Writing in the Teaching of a Second Language
}

\author{
Sonia López ${ }^{1}$ Edwin Santamaría-Freire ${ }^{2}$
}

\begin{abstract}
The correct use of a foreign language is based on receptive and communicative skills. Within the communicative skills is writing which needs certain elements for its realization, among them time and effort on the part of the students and of teachers? The present work is carried out by 256 young students who present shortcomings in the grammatical and evaluation elements used by the institution within the written compositions that they perform as part of the final exam of each semester. Although, there are differences between the intervened groups due to the methodological strategy implemented in a sequential way, this time the feedback, it does not manage to cancel the production of errors more if they decrease their presence within the grammar and evaluation elements. Therefore, it is important to develop teacher's feedback and manage students' emotional intelligence.
\end{abstract}

Keywords - feedback; grammar; writing.

\section{INTRODUCTION}

At present, people choose to study the different languages for professional or personal reasons. In relation to the English language, it must be considered as the scientific language [1], because researchers, teachers and students write their works in this language for their dissemination.

Due to the demand of some components for its realization as for example the grammatical elements and indicators of evaluation, which are acquired by means of the practice and the time employed by the people involved in the process of teaching the language. In this line, are Watcharapunyawong and Yusaha [2] who say that the ability to write is difficult to be assimilated.

And of course, it must be considered that there are difficulties that the student must face and overcome in the process of learning the language that he has chosen to study it. As García [3], points out "students come to university with no experience in writing in a foreign language" (p. 27) because writing isolated or in-context sentences does not mean that they can write correctly.

From the above, it is possible to formulate the research question "what are the main problems in English writing?". This based on the problematic revision of the previously reviewed works, in addition, a problematic analysis of the students of the specialized Department of Languages. All this together allows rising as goal objective: Identify the shortcomings in the writing of the semester final exams.

\footnotetext{
${ }^{1,2}$ Universidad Técnica de Ambato.
}

\subsection{Evolution of the English language}

The English language is used for researchers, teachers and the public to publicize their work, so per Rajadell [4], it is in second place at the language level. For this reason, the United States (USA) and the United Kingdom (UK) are used as references for teaching English.

For this reason, it is taken as a reference for its study a point in time. And is that "it was from World War II that English gained popularity and was promoted as the main foreign language" ([5] p. 448 in the USA. A summary of the most relevant dates while diffusion of the English language as a foreign language (FL) is presented in the Strength Through Wisdom report, 1979. It was shown that Americans and Americans had limited communication skills in the field of foreign languages [6].

English language was promoted through the United States Congress through the document known as Goals 2000. That is, the foreign language was included in the subjects in which students had to prove to be competent [7]. Subsequently, the document known as Standards for Foreign Learning: Preparing for the 21st Century [8] which referred mainly to "what students know and are able to do" (p.1) In other words, the human being is privileged rather than the content to be covered. On the other hand, in the United Kingdom, the year 1995 was taken as a reference because there was the incentive for studying foreign languages were initiated [9]. After that, it would be added several documents that promoted its diffusion and study.

Namely, the Council Resolution, March 31th, 1995, which is on improving the quality and diversification of the learning of language teaching in the education systems of the European Union (EU) This document states that students should have as a rule the possibility of learning "two languages of the union other than the mother tongue " [9] (p. 518). In addition, the studies of foreign languages were managed at various times over time, due to the ease of mobilization and contact of people with foreign languages. Finally, the Barcelona European Council proposes "... to promote professional qualifications and mobility in the European Union ..." [10] (p. 259), because of the growing demand for people to learn languages.

Each person has their own way of acquiring a second language. A very general definition would be "it is the process of learning another language after the first language has been acquired" [11] (p. 14), this concept can be applied to both a second language and a foreign language. At the beginning of the 1970's, researchers have dealt with the issue of second- 
language acquisition, so they were interested in studying both the differences and the similarities between the first language and the second language. And they came to establish that the acquisition of a second language was affected to a different degree by the mother tongue in the process of acquisition of the second language [12].

In 1942 the US government convened fifty-five universities to attempt to develop programs and methods for teaching languages [13]. The methods were the following: the silent method, lingual audio, cognitive code, total physical response, suggested [14]. While in the European Union the methods were developed: grammar translation, direct method, natural approach, communicative approach [15]. Each method has contributed to the learning of a foreign language at various points of time and its contribution has been and will be important within the language study. According to MuñozBasols [16] are the following: the narrative text, expository text, argumentative text, journalistic text, advertising text, legal and administrative text, scientific-technical text. Each text has its own characteristics and pre-determined level of study of the language learning.

During this process, it is common to observe that students make different mistakes. The classification of errors can be distinguished from Odlin [15], which maintains the challenge of Error Analysis (EA), which categorizes the error committed by a student in his/her communication process. The EA makes possible to distinguish between inter-linguistic errors which are "attributed to the native language" and intralinguistic errors are "those of the language that is being learned and which have no relation to the mother tongue" [17] (p. 92).

There are several classifications of errors, which obey both the objectives of the researcher and the context in which they are studied. In relation to the grammatical component Terrel (1991) cited by Mestre [18] mentions that within the communicative competence the grammatical part is important. Within the reviewed works that are presented: The University of Jaén, on the skill written in English. And among the results had found them, we had that university students have problems in the handling of verbs, adjectives and nouns. Likewise, an Iranian study on some grammatical elements [19] was found and among the mistakes that students made were the handling of articles, verbs, prepositions, pronouns articles (they are part of the determinants). Each work from its different approaches agrees that the grammatical elements are difficult to handle in the written skill of the English language.

On vocabulary, there was no correct management of English structures coupled with the lack of motivation for writing in English [20]. DEDI students done especially descriptive compositions. Like the work of Emmaryana [21], who worked on grammatical errors. On the other hand, as far as the organization in general are disordered, because there is no logical sequence and the main idea is not supported with secondary ideas it does not provide sequential details. The classification of errors is based on errors of location, description, hypotheses, research on communication effects and didactics Spillner [22], from what can be inferred that: the grammatical elements are the main problem that we must be taken into consideration for studying a language. Tan [23] concepts that agree with Chan [24] mentioning that grammatical errors are within the ten mistakes made by Chinese students.

It is common to see that from composition to composition there are "the same mistakes that are made by the student again and again" [25], which indicates the absence of teaching strategies for writing, which in this case would be taken as a failure in the development of this skill in learning. As for the elements of evaluation, they are determined by the Department of Languages based on its curriculum. Namely, it's spelling and punctuation, organization, fluency, grammar and vocabulary. [31] Also, within the grammatical elements are: nouns, verbs, adjectives, adverbs, determinants, prepositions, pronouns, conjunctions, and exclamations [26].

\section{II.METHODOLOGY}

The present research work is based on the socio-critical paradigm, as Popkewitz \& Fendler [27] said that stating that the integration of all participants is basic to find solutions to the problems. In addition, the work has a quantitative approach because it contains numerical data that will serve to contrast with the hypotheses ([30]. And the necessary elements to develop the research under the descriptive approach [28], since the results obtained by means of the questionnaire elaborated and validated for the present work are presented. The design is pre-experimental since it counted on the participation of students assigned by secretary to the respective parallels.

As for the literature reviewed, there are [19], [20], [21] and [24]. These works have contributed significantly to the search for answers to the failures of the students of the Language Specialist Department, which must get the requirement to approve a foreign language in order to be able to graduate students from their respective careers [29].

The Specialized Language Department (DEDI) attends an average of 5000 students per semester in the different foreign languages, English language is being the most demanded by students whose ages range from 18 to 22 years. And it is through their collaboration that they wanted to identify their shortcomings at the time of writing. As writing is a skill that demands time and effort, the present research has been carried out in three levels, Beginner A1, Elementary A2 and Preintermediate B1 in the DEDI at Technical University of Ambato.

As for the students who participated in the present work we have worked with two independent groups of students, who had written compositions of the final exam of each semester. Namely, the intervention group consisted of 123 students without replacement, and the control group by 133 independent students at different levels of control.

For the collection of information regarding the development of writing skills, a questionnaire was developed, which contained structured questions, closed-ended questions, multiple-choice questions about students' perceptions of Teaching of the skill, the work of the teacher and the performance of the students when they carry out their written works. The present instrument had Cronbach's alpha of 0.836 . A pilot test was carried out on 38 students of similar 
characteristics to the students participating in the research work within the same department which allowed improving the instrument in relation to the formulation of questions to make it easy for students to understand.

\section{RESULTS}

The most relevant data obtained in the two moments of the investigation are presented. Through the questionnaire elaborated it has been possible to gather information regarding the students 'perception and teachers' performance in the development of written compositions.

It has been possible to establish that $53 \%$ of the students' state that the grammatical errors affect their written work despite the work carried out by the teacher in classes. In addition, they state that their shortcomings are not recent, but rather have been scarce since their secondary education. And because of this weakness, they generate a desire to improve their performance by performing the different written works.

The students state that per the freedom of teaching, the teacher establishes when and the time to be used for the preparation of written works that are established in the guidebook used at different levels. Fig. 1

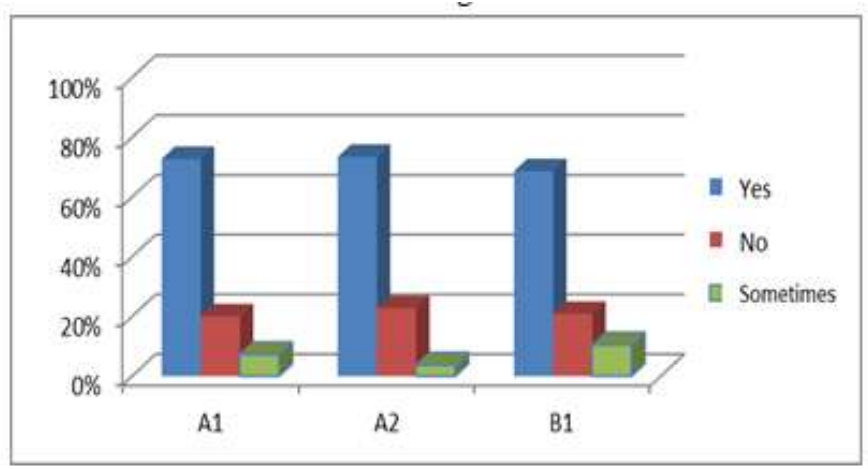

Fig. 1. Motivation towards written exercises at all three levels

Teachers should consider the different learning styles of students, so that teachers should use different methods or techniques to encourage the development of written work. As well as, the way of realize them either individually, in pairs or in groups always with the aim of motivating intrinsically and extrinsically to the students.

It was found that the teacher in use of the freedom of professorship chooses how to provide the qualification of the written works. Among the most used are symbols and codes previously socialized with students, or personal corrections for their students in grammar and evaluation indicators used in written compositions.

\begin{tabular}{|c|c|c|c|c|c|c|c|c|c|c|c|c|}
\hline & \multicolumn{12}{|c|}{$\begin{array}{l}\text { Considera, que dentro de la destreza de escritura, con respecto a los niveles pasados } \\
\text { usted }\end{array}$} \\
\hline & \multicolumn{4}{|c|}{ Nivel A1 } & \multicolumn{4}{|c|}{ Nivel A2 } & \multicolumn{4}{|c|}{ Nivel B1 } \\
\hline & \begin{tabular}{|l} 
linds of \\
sciesto
\end{tabular} & $\begin{array}{c}\text { Du } \\
\text { scuesto }\end{array}$ & 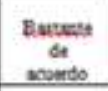 & 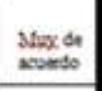 & \begin{tabular}{|l} 
Siate da \\
scomedo
\end{tabular} & $\underset{\text { neverdo }}{\mathrm{De}}$ & $\begin{array}{l}\text { Bartes: } \\
\text { ot } \\
\text { someto }\end{array}$ & $\begin{array}{l}\text { Shax do } \\
\text { cosimdo }\end{array}$ & $\begin{array}{l}\text { Siate de } \\
\text { cosemdo }\end{array}$ & $\begin{array}{c}\text { De } \\
\text { scouedo }\end{array}$ & $\begin{array}{c}\text { Eursest } \\
\text { de } \\
\text { coumbo }\end{array}$ & $\begin{array}{l}\text { Stow do } \\
\text { scuedo }\end{array}$ \\
\hline $\begin{array}{l}\text { Ha disminuido los errores } \\
\text { gramaticales en relación al } \\
\text { nivel anterior. }\end{array}$ & $4.5 \%$ & $8.1 \%$ & $3.6 \%$ & $7.2 \%$ & $1.5 \%$ & $1.5 \%$ & $2.7 \%$ & $2.7 \%$ & $3.8 \%$ & $2.3 \%$ & $9.8 \%$ & $3.8 \%$ \\
\hline $\begin{array}{l}\text { Ha mantenido los mismos } \\
\text { errores gramaticales que en } \\
\text { el nivel anterior. }\end{array}$ & $6.3 \%$ & $2.7 \%$ & $0.0 \%$ & $0.9 \%$ & $0.2 \%$ & $4.0 \%$ & $5.3 \%$ & $8.9 \%$ & $9.4 \%$ & $3.8 \%$ & $3.8 \%$ & $2.8 \%$ \\
\hline $\begin{array}{l}\text { Los errores gramaticales se } \\
\text { han incrementado en este } \\
\text { nivel }\end{array}$ & $8.1 \%$ & $5.4 \%$ & $0.9 \%$ & $2.7 \%$ & $5.1 \%$ & $2.7 \%$ & $9.1 \%$ & $1.5 \%$ & $5.3 \%$ & $6.8 \%$ & $8.3 \%$ & $9.4 \%$ \\
\hline $\begin{array}{l}\text { Ha mejorado el desemperio } \\
\text { dentro de la escritura en el } \\
\text { idioma ingles }\end{array}$ & $6.3 \%$ & $0.0 \%$ & $5.4 \%$ & $9.0 \%$ & $5.4 \%$ & $7.7 \%$ & $2.7 \%$ & $6.5 \%$ & $3,8 \%$ & $2.3 \%$ & $2.3 \%$ & $1.3 \%$ \\
\hline $\begin{array}{l}\text { Ha mantenido el desempeño } \\
\text { en la escrituras dl idioma } \\
\text { inglés }\end{array}$ & $8.1 \%$ & $0.9 \%$ & $7.2 \%$ & $3.6 \%$ & $2.7 \%$ & $0.2 \%$ & $2.7 \%$ & $2.7 \%$ & $3.8 \%$ & $8.3 \%$ & $3.8 \%$ & $3.8 \%$ \\
\hline $\begin{array}{l}\text { Ha disminuido el } \\
\text { desermpeño en la escritura } \\
\text { del idioma ingles }\end{array}$ & $3.6 \%$ & $0.0 \%$ & $9.0 \%$ & $5.4 \%$ & $7.7 \%$ & $1.5 \%$ & $6.5 \%$ & $2.7 \%$ & $2.3 \%$ & $5.3 \%$ & $1.3 \%$ & $0.8 \%$ \\
\hline
\end{tabular}

From the tabulation of errors were found in the written compositions of the students in the different levels. It was possible to establish an average of errors in each one of the established elements. From the data obtained it has been possible established that the students of the DEDI do not have a uniform performance in the management of the different elements present in the composition since their management differs from level to level. 

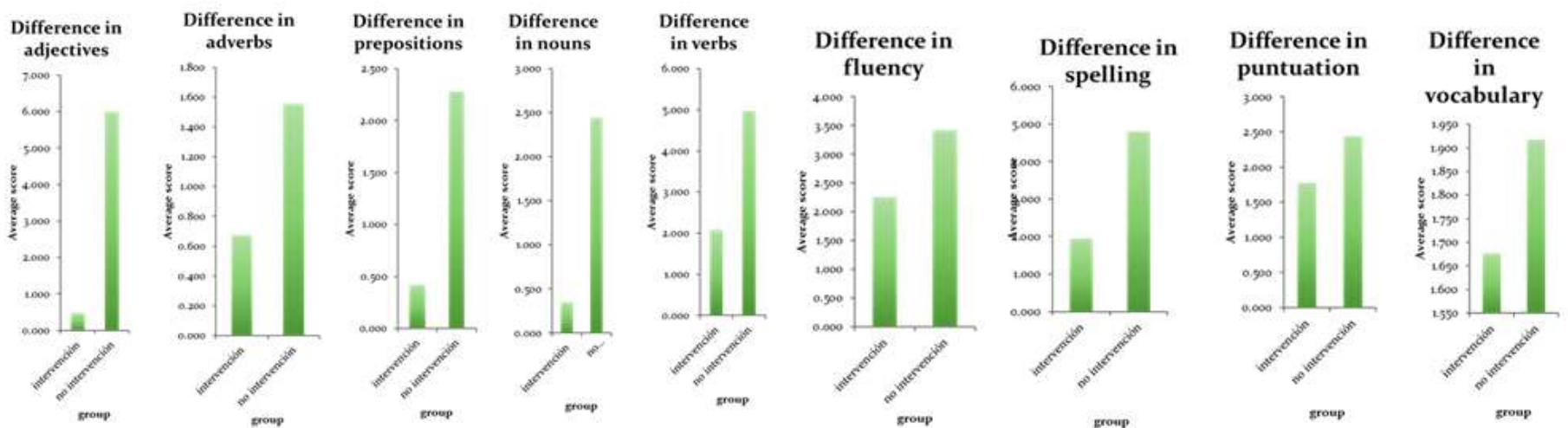

Fig. 2. Elements with fewer errors.

Source: Compositions of the final exams of each level.

As can be seen, the implementation of feedback has been significant in the handling of grammatical elements, as it has been possible to reduce the number of errors present in each level. Although it has not been achieved uniformity in all, if it has been possible to improve the performance of the students through the intervened levels regarding subjects and verbs in the levels Beginner A1 and Pre-intermediate B1.

The elemental level A2 presents a decrease of errors in all the grammatical elements even though they have not been able to eliminate them, since they are considered like part of the process of learning of the language. And in the Beginner A1 level it has managed to reduce the errors in the elements present in table 1 .

\section{CONCLUSIONS}

At the end of this research process it was possible to establish the following conclusions: The presence of errors in the different grammatical elements has been detected in the compositions of the final examinations carried out by the students of the three intervened levels. From the data obtained it can be established that there is no homogeneous management of the same by the students. However, a good management of these elements was already indicated by Tan, when he makes the classification of the thirteen errors.

In the Beginning, A1 level, difficulties have been encountered in the management of adverbs. In this line the work by Chan indicates that difficulties were encountered in the handling of adverbs and prepositions. In the Elementary level A2 positive results were obtained in the decrease of errors in all the grammatical elements. And in the Preintermedia B1 level were found shortcomings in the management of determinants and pronouns. It's related with the work of Taghavi.

In relation to the evaluation indicators used by the Specialized Language Department, progress has been observed in most of them by the students during the three intervened semesters.

It should be noted that the vocabulary that is used coincides with the work done by Diez-Bedmar, since in the Beginner A1 and Elementary A2 level there is a limited use of it. This was detected and based on the practice of a part-guided composition of teachers. This is an indicator that it must be implemented because otherwise it would be part of the work carried out by Ningsih in which it is pointed out that there is weakness in the management of the vocabulary added to the desmotivation on the part of the students to carry out the written works.

\section{REFERENCES}

[1] Ammon, U. (2010). Información mundial sobre las ciencias sociales 2010 Spanish. México: Unesco.

[2] Watcharapunyawong, S. \& Yusaha, S. (2012). Thai EFL students' writing error in different text types. The interference of the first language. En English language Teaching. 6 (1), 67-78. Nakhon Rachasima: Suranaree University of Technology: https://doi.org/10.5539/elt.v6n1p67

[3] García, M. (1998). Metodología para el aprendizaje de la expresión escrita en lengua inglesa en bachillerato. Tesis doctoral. Jaén, Universidad de Jaén.

[4] Rajadell, M. (2009) Creación de empresas. (3a. ed.). Barcelona: Universitat Politécnica de Catalunya.

[5] Zaccagnini de Ory, E. (2009). El mundo estudia español. 2009. Madrid: Ministerio de Educación

[6] Goulah, J. (2011). From abstraction and militarization of language education to society for language education: Lessons from Daisaku Ikeda and Tsunesaburo Makiguchi. En K. Saltman y D. Gabbard (Eds.). Education as enforcement: The militarization and corporatization of schools (2a. ed.) (pp. 173-175). New York, NY: Taylor \& Francis.

[7] Shrum, J. \& Glisan, E. (2010). Teacher's Handbook: Contextualized Language Instruction. (4a. ed.). Boston: Cengage.

[8] Phillips, J. \& Abbott, M. (2011). A Decade of Foreign Language Standards: Impact, Influence, and Future Directions. Alexandria, VA: ACTFL.

[9] Susz, P. (2005). Lengua y ser. En La diversidad asediada: Escritos sobre culturas y mundialización. La Paz. (pp. 518 - 522). La Paz: Plural editores.

[10] Meno, F. (2002). Un nuevo marco para la enseñanza y el aprendizaje de idiomas. Revista de educación. 329. (331), 257-261.

[11] Yang, X. \& Xu, H. (2001). Theories of error analysis. En Errors of creativity: An analysis of lexical errors committed by Chinese ESL students. (pp. 9-17). Maryland: University Press of America, Inc.

[12] Nunan, D. (2011). Teaching English to Young learners. Anaheim, CA: Anaheim University Press.

[13] Zanón, J. (2007). Psicolingüística y didáctica de las lenguas: Una aproximación histórica y conceptual. Marco ELE Revista de didáctica ELE. 5, (1-30).

[14] Richards, J. \& Rodgers, T. (2014). Approaches and methods in language teaching. (3a. ed.). Cambridge: Cambridge University Press.

[15] Odlin, T. (1997). Problems with contrastive analysis. En Language transfer: Cross-linguistic influence in language learning. (6a.ed.). (pp. 17-20). Cambridge: Cambridge University Press.

[16] Muñoz- Basols, J., Pérez, Y. \& David, M. (2012). Developing writing skills in Spanish. New York: Routledge. 
[17] Gass, S., Benney, J. \& Plonsky, L. (2013). Error analysis. En S. Gass (Ed.) Second language acquisition: An introductory course (4a.ed.). (pp.91-96). Collepino: Routledge. https://doi.org/10.1007/978-1-4419-1153-7_200190

[18] Mestre, E. (2011). Error in the learning and teaching of English as a second language at higher education level. Tesis doctoral. Universitat Politécnica de Valencia, Valencia.

[19] Taghavi, M. (2012). Error analysis in composition of Iranian lower Intermediate students. Rasht: Guilan University.

[20] Ningsih, R. (2004). Error analysis in the students' English writing: a case study with the second year students of SLTPN 239 Tanjung Barat. Jakarta: Syarif Hidayatullah State Islamic University.

[21] Emmaryana, F. (2010). An analysis on the grammatical error in the students' writing. Degree of S. Pd (Bachelor of Arts) in English Language Education. Jakarta, Syarif Hidayatullah State Islamic University.

[22] Spillner, B. (1991). Introduction. En Error analysis: A comprehensive bibliography. (pp. XIII -XV). Amsterdam: John Benjamins Publishing. https://doi.org/10.1075/lisl.12

[23] Tan, H. (2006). A study of EFL learners' writing errors and instructional strategies. Taiwan: Kun Shan University.

[24] Chan, Y. (2004). Syntactic transfer: Evidence from the interlanguage of Hong Kong Chinese ESL learners. The Modern Language Journal. 88 (1), 56-74. https://doi.org/10.1111/j.0026-7902.2004.00218.x

[25] Mora-Flores, E. (2009). Writing instruction for English learners. A focus on genre. California: Corwin Press.

[26] Spratt, M., Pulverness, A. y Williams, M. (2005). The TKT Teaching Knowledge Test Course. Cambridge: Cambridge University Press.

[27] Popkewitz, T. \& Fendler, L. (1999). Critical Theories in Education: Changing Terrains of Knowledge and Politics. London: Routledge.

[28] Méndez, C. (2011). Methodology. Design and development of the research process. México: Limusa.

[29] Ley Orgánica de Educación Superior. (2010). Registro Oficial. Ministerio de Educación.

[30] Hernández, R., Fernández, C. y Baptista, M. (2010). Metodología de la investigación. México D.F.: Mcgraw-Hill.

[31] Diez-Bedmar, M. (2011). Spanish pre-university students' use of English: CEA results from the University Entrance Examination. International Journal of English Studies. Murcia: University of Murcia. 